\title{
Устойчивость амфиплоидов пшениц к возбудителю бурой ржавчины
}

\author{
Н.П. Гончаров ${ }^{1,2} 凶$ Р.Л. Богуславский ${ }^{3}$ Е.А. Орлова ${ }^{4}$, М.Х. Белоусова ${ }^{5}$, Н.Х. Аминов ${ }^{6}$, \\ А.А. Коновалов ${ }^{1}$, Е.Я. Кондратенко ${ }^{1}$, Е.И. Гультяева ${ }^{7}$
}

Аннотация: Изучена возрастная и ювенильная устойчивость к бурой ржавчине (Puccinia triticina Erikss.) 108 искусственных амфиплоидов (амфидиплоидов) пшениц, различающихся геномной формулой и происхождением (Россия, США, Япония, Мексика, Болгария, Азербайджан и др.). С использованием молекулярных методов у 35 линий проведена идентификация генов Lr. Свыше 60 \% амфиплоидов характеризовались разной степенью устойчивостью в полевых условиях в Новосибирске и Харькове. Число образцов, устойчивых в фазе проростков, было значительно ниже, что указывает на наличие у них явно выраженной возрастной устойчивости к ржавчине. В результате полевой и лабораторной оценок выделено три амфиплоида, высокоустойчивых к бурой ржавчине на протяжении всего периода вегетации, - KU 233, KU 221-21, Triticum kiharae (к-47897). С помощью молекулярных методов у изученных амфиплоидов не обнаружено генов $L r 24, L r 41, L r 47, L r 20, L r 26$, при этом выявлены носители генов $L r 1$, Lr9, Lr10, Lr19, Lr28, Lr34, Lr37. Даны рекомендации по использованию искусственных амфиплоидов в селекции мягкой пшеницы на устойчивость к бурой ржавчине.

Ключевые слова: биоресурсные коллекции; искусственные амфиплоиды; устойчивость к болезням; бурая ржавчина; исходный материал.

Благодарности: Работа частично финансировалась по базовому проекту ИЦиГ СО РАН № 0324-2019-0039-С-01.

Для цитирования: Гончаров Н.П., Богуславский Р.Л., Орлова Е.А., Белоусова М.Х., Аминов Н.Х., Коновалов А.А., Кондратенко Е.Я., Гультяева Е.И. Устойчивость амфиплоидов пшениц к возбудителю бурой ржавчины. Письма в Вавиловский журнал генетики и селекции. 2020 6(3):95-106. DOI 10.18699/Letters2020-6-14

\section{Leaf rust resistance in wheat amphidiploids}

N.P. Goncharov ${ }^{1,2} \bowtie$, R.L. Boguslavsky ${ }^{3}$, E.A. Orlova ${ }^{4}$, M.Kh. Belousova ${ }^{5}$, N.Kh. Aminov ${ }^{6}$, A.A. Konovalov ${ }^{1}$, E.Ya. Kondratenko ${ }^{1}$, E.I. Gultyaeva ${ }^{7}$

Abstract: Adult and juvenile resistance to leaf (brown) rust (causal agent - Puccinia triticina Erikss.) was studied in 108 accessions of artificial wheat amphidiploids with different genomic formula and different origin (Russia, USA, Japan, Mexico, Bulgaria, Azerbaijan, etc.). The $L r$ genes were identified using molecular markers in 35 of them. More than $60 \%$ of the studied amphidiploids were characterized by varying degrees of leaf rust resistance in Novosibirsk and Kharkov field conditions. The number of them was resistant in the seedling

\footnotetext{
Федеральный исследовательский центр Институт цитологии и генетики Сибирского отделения Российской академии наук, Новосибирск, Россия

${ }^{2}$ Новосибирский государственный аграрный университет, Новосибирск, Россия

${ }^{3}$ Институт растениеводства им. В.Я. Юрьева Национальной академии аграрных наук Украины, Харьков, Украина

Сибирский научно-исследовательский институт растениеводства и селекции - филиал Федерального исследовательского центра

Институт цитологии и генетики Сибирского отделения Российской академии наук, Краснообск, Новосибирская область, Россия

Дагестанская опытная станция - филиал Федерального исследовательского центра Всероссийский институт генетических ресурсов растений им. Н.И. Вавилова (ВИР), Дагестан, Россия

${ }^{6}$ Институт генетических ресурсов Национальной академии наук Азербайджана, Баку, Азербайджан

Всероссийский научно-исследовательский институт защиты растений, Пушкин, Санкт-Петербург, Россия

' Institute of Cytology and Genetics of Siberian Branch of the Russian Academy of Sciences, Novosibirsk, Russia

${ }^{2}$ Novosibirsk State Agrarian University, Novosibirsk, Russia

${ }^{3}$ The Plant Production Institute named after V.Ya. Yuryev of the National Academy of Agrarian Sciences of Ukraine, Kharkov, Ukraine

${ }^{4}$ Siberian Research Institute of Plant Production and Breeding - Branch of the Institute of Cytology and Genetics of Siberian Branch of the Russian Academy of Sciences, Krasnoobsk, Novosibirsk region, Russia

${ }^{5}$ Dagestan Experimental Station - Branch of the Federal Research Center the N.I. Vavilov All-Russian Institute of Plant Genetic Resources (VIR), Dagestan, Russia

${ }^{6}$ Genetic Resources Institute of the Azerbaijan National Academy of Sciences, Baku, Azerbaijan

7 All Russian Research Institute of Plant Protection, Pushkin, St. Petersburg, Russia

هe-mail: gonch@bionet.nsc.ru

() Гончаров Н.П., Богуславский Р.Л., Орлова Е.А., Белоусова М.Х., Аминов Н.Х., Коновалов А.А., Кондратенко Е.Я., Гультяева Е.И., 2020
} 
phase. The resistance in this phase was significantly lower, which indicates the presence of clearly grazed age-related rust resistance in the studied amphidiploids. As a result of field and laboratory tests, three amphidiploids were identified that were highly resistant to brown rust, namely KU 233, KU 221-21, and Triticum kiharae (k-47897). Using molecular methods, Lr24, Lr41, Lr47, Lr20, and Lr26 genes weren't detected in the studied amphidiploids, while carriers of the $L r 1, \operatorname{Lr} 9, \operatorname{Lr} 10, \operatorname{Lr} 19, \operatorname{Lr} 28, \operatorname{Lr} 34$, and $\operatorname{Lr} 37$ genes were identified. Recommendations on the use of artificial amphidiploids in the breeding of common wheat for resistance for leaf rust are given.

Key words: biodiversity collections; artificial amphidiploids; disease resistance; leaf (brown) rust; plant breeding initial materials.

Acknowledgements: The work was partially carried out under the budget project of the ICG SB RAS No. 0324-2019-0039-C-01.

For citation: Goncharov N.P., Boguslavsky R.L., Orlova E.A., Belousova M.Kh., Aminov N.Kh., Konovalov A.A., Kondratenko E.Ya., Gultyaeva E.I. Leaf rust resistance in wheat amphidiploids. Pisma v Vavilovskii Zhurnal Genetiki i Selektsii = Letters to Vavilov Journal of Genetics and Breeding. 2020;6(3): 95-106. DOI 10.18699/Letters2020-6-14. (in Russian)

\section{Введение}

Серьезной проблемой при селекции большинства сельскохозяйственных культур, включая мягкую пшеницу (Triticum aestivum L.), является крайне узкое генетическое разнообразие заселектированных за последнее столетие коммерческих сортов. Создание генотипов возделываемых растений, устойчивых к абиотическим и биотическим стрессам, в том числе связанным с локальным и глобальным изменениями климата, и новых способов обработки почвы, нарушения севооборотов и бесконтрольная интродукция семенного материала на основных сельскохозяйственных территориях приводят к изменению видового состава возбудителей болезней сельскохозяйственной культур (Афанасенко и др., 2015), а следовательно, к изменению патогенной нагрузки, настоятельно требуя расширения биоразнообразия возделываемых видов пшениц. При решении этой проблемы исследователи возлагают основные надежды на использование генетического материала диких видов-сородичей возделываемых культур (Stoyanov, 2014; Brozynska et al., 2015), а также культурных видов, в настоящее время выведенных из возделывания (не культивируемых вообще или культивируемых на незначительных площадях) (Zakharieva et al., 2010; Longin, Würschum, 2016). Среди наиболее перспективных доноров хозяйственно важных признаков для мягкой пшеницы исследователи выделяют донор ее D генома Aegilops squarrosa L. (= syn. Ae. tauschii Coss.) (Лайкова и др., 2013; Потоцкая и др., 2018; Li et al., 2018), а одновременно для мягкой и твердой пшениц - некоторые виды эгилопсов группы Sitopsis, в том числе Ae. speltoides Tausch - донор их В генома (Salina et al., 2011; Плотникова и др., 2018). Из видов, выведенных из возделывания, наиболее перспективными донорами хозяйственно важных признаков считают полбу Triticum dicoccum (Schrank.) Schuebler (Zaharieva et al. 2010) и T. timopheevii (Zhuk.) Zhuk. (Леонова и др., 2008; Leonova et al., 2011). Примером эффективного переноса устойчивости от данных видов в мягкую пшеницу служат образцы с генами $L r 21$ (от англ. leaf rust resistance), Lr22a, Lr32 и Lr39 (= Lr41) от Ae. tauschii; Lr28, Lr35, Lr47, Lr51 и Lr66 от Ae. speltoides и Lr18 от T. timopheevii ${ }^{1}$.

Один из эффективных методов передачи генетического материала от диких видов-сородичей в возделываемые полиплоидные виды - это использование искусственных (синтетических, или рукотворных) амфиплоидов (Spetsov, Savov,

\footnotetext{
${ }^{1}$ McIntosh R.A., Yamazaki Y., Dubcovsky J. et al. Catalogue of gene symbols for wheat [Электронный ресурc]. URL: http://www.shigen. nig.ac.jp/wheat/komugi/genes/symbolClassList.jsp (дата обращения: 30.07.2020).
}

1992; Plamenov, Spetsov, 2011; Stoyanov, 2014; Das et al., 2016; Morgounov et al., 2017; Li et al., 2018). Унаследовав от диких видов-сородичей ценные признаки, эти формы стали более удобными донорами для передачи хозяйственно важных признаков в пшеницу, чем непосредственно применяемые в интрогрессивной гибридизации дикие виды (Давоян и др., 2014; Nyine et al., 2020). В течение десятилетий амфиплоиды интенсивно, в больших масштабах создавались в Японии (Catalogue..., 1997/1998), Мексике (Majeeb-Kazi et al., 1996; Kishii, 2019), Болгарии (Spetsov, Savov, 1992; Plamenov, Spetsov, 2011; Stoyanov, 2014), Азербайджане (Gadimaliyeva et al., 2018), Российской Федерации (Жиров, Терновская, 1993; Зарубайло, Таврин, 1972; и др.) и других странах. Они успешно используются в различных селекционных программах (Лайкова и др., 2013; Li et al., 2018). В настоящее время в ряде генбанков мира имеются значительные коллекции искусственно созданных амфиплоидов. Наиболее репрезентативная коллекция поддерживается в Киотском университете (Catalogue..., 1997/1998), Институте растениеводства им. В.Я. Юрьева (Харьков, Украина), The John Innes Centre (Норвич, Великобритания), небольшие - во Всероссийском институте генетических ресурсов растений им. Н.И. Вавилова (Санкт-Петербург, Россия), The Small Grains Collection (Абердин, США), Leibnitz Institute of Plant Genetics and Crop Plant Research (Гатерслебен, Германия) и в СІMМYТ (Эль-Батан, штат Каретаро, Мексика). Заметим, что в коллекциях большинства европейских генбанков амфиплоиды как таковые отсутствуют. Исключение - генбанк Вагенингенского университета (Нидерланды), в котором под именем «амфиплоид» (амфидиплоид) хранятся межродовые гибриды, беккроссированные на мягкую пшеницу.

Для более эффективного использования этого материала в селекции актуальна не только инвентаризация ранее созданных форм, но и всестороннее изучение, в том числе по устойчивости к болезням. Наиболее распространенное заболевание пшеницы во всех зонах возделывания этой культуры - бурая ржавчина (возбудитель - Puccinia triticina Erikss.).

Цель данной работы - изучение образцов искусственно созданных (рукотворных) амфиплоидов, хранящихся в российских и зарубежных генбанках, по устойчивости к возбудителю бурой ржавчины и идентификация у них генов $L r$.

\section{Материалы и методы}

Материал для исследований получен из генбанков Киотского университета (Япония), Всероссийского института генетических ресурсов растений им. Н.И. Вавилова (СанктПетербург, Россия), The Small Grains Collection (Абердин, 
США), Института растениеводства им. В.Я. Юрьева (Харьков, Украина) и других учреждений.

Предварительно весь материал был охарактеризован по запасным белкам (глиадинам) (Goncharov et al., 2007). Heаутентичные по данному признаку образцы искусственных амфиплоидов были исключены из эксперимента (например, PI254218 T. timococcum Kost., PI282931 T. soveticum ssp. fungicidum (Zhuk.) N.P. Gontsch.). Всего для иммунологических исследований отобрано 108 амфиплоидов, различающихся геномной формулой и происхождением. В Харькове при озимом и яровом посевах в полевых условиях в разные годы (1995-2006, 2014) были изучены 87 амфиплоидов. В озимом посеве в Новосибирске амфиплоиды с озимым типом развития показали низкую зимостойкость, в связи с чем в 2015 г. исследовали только яровые образцы, и дополнительно были добавлены яровые амфиплоиды из коллекции Университета г. Киото (Япония), охарактеризованные ранее по типу развития (Гончаров, 2012).

Устойчивость образцов амфиплоидов в полевых условиях изучали на фитоучастке Сибирского научно-исследовательского института растениеводства и селекции (СибНИИРС, Краснообск, Новосибирская область) и коллекционном участке Института растениеводства им. В.Я. Юрьева (Харьков, Украина) на естественном инфекционном фоне. Степень поражения образцов бурой ржавчиной в полевых условиях Новосибирска оценивали по шкале Петерсона (в \%) (Peterson et al., 1948), в условиях Харькова - по 10-балльной шкале ВИР, где балл 9 - высокая устойчивость (пораженность растения 0 \%), балл 0 - 100 \% поражение растений (Методические указания..., 1962).

В лабораторных условиях Всероссийского НИИ защиты растений исследовали ювенильную устойчивость амфиплоидов к возбудителю бурой ржавчины (фаза первого листа). Для этого применили метод инокуляции отрезков листьев, помещенных в раствор бензимидазола (Михайлова и др., 1998), и заражение проростков пшеницы, выращенных в сосудах с почвой (фаза первого листа). Устойчивость отрезков листьев проростков растений изучили с использованием пяти географически отдаленных популяций P. triticina (томская, омская, ростовская, краснодарская и дагестанская), собранных с сортов мягкой пшеницы в 2010 г., и тест-клона К9, маркированного вирулентностью к гену Lr9, контролирующему устойчивость к бурой ржавчине. Для инокуляции интактных листьев растений была взята сборная дагестанская популяция патогена, собранная с коллекционных образцов мягкой пшеницы на экспериментальном посеве Дагестанской опытной станции (ДОС) ВИР в 2014 г., и три тест-клона (kLr9, kLr19, kLr26). Все популяции и тест-клоны были авирулентны (баллы 0, 0;) к линиям TcLr24, TcLr28, TcLr29, KS90WGRC10 (Lr41), TcLr45, сорту Pavon (Lr47) и вирулентны (баллы 3 и 4) к линиям TcLr3a, TcLr3bg, TcLr3ka, TcLr10, TcLr11, TcLr12, TcLr13, TcLr14a, TcLr14b, TcLr16, TcLr17, TcLr18, TcLr21, TcLr22a, TcLr30, TcLr32, TcLr33, TcLr34, TcLr35, TcLr37, copту Pavon 76 (Lr46), линиям CSP44 (Lr48), VL404 (Lr49), TcLrB, TcLr52 (=W). Различие между популяциями отмечено на изогенных линиях TcLr1, TcLr2a, TcLr2b, TcLr2c, TcLr9, TcLr15, TcLr19, TcLr20, TcLr23, TcLr26, TcLr44 и линии KS96WGRC36 (Lr50) (табл. 1).
Реакцию отрезков листьев на заражение патогеном определяли через 7-8 дней после инокуляции; интактных растений - через 10-12 дней. Использовали балловую шкалу Майнса и Джексона, где 0 - отсутствие симптомов; 0; - некрозы без пустул; 1 - очень мелкие пустулы, окруженные некрозом; 2 - пустулы среднего размера, окруженные некрозом или хлорозом; 3 - пустулы среднего размера без некроза, 4 - пустулы крупные, иногда сливающиеся, без некроза; X - пустулы на одном и том же листе разных типов, присутствуют хлорозы и некрозы (Mains, Jackson, 1926).

Для идентификации тринадцати Lr-генов (Lr1, Lr9, Lr10, Lr19, Lr20, Lr24, Lr26, Lr28, Lr34, Lr35, Lr37, Lr41 и Lr47) (табл. 2) использовали амплификацию ДНК, которую выделяли из листьев 10-дневных проростков микрометодом по методике Edwards et al. (1991) в модификации Д.Б. Дорохова и Э. Клоке (1997). Амплификацию проводили в реакционной смеси по предложенным в литературе протоколам.

В качестве отрицательного контроля в экспериментах использовали восприимчивый сорт яровой мягкой пшеницы Thatcher, а положительного - его изогенные линии с идентифицируемыми генами $L r$. Амплифицированные фрагменты ДНК разделяли электрофорезом в $1.5 \%$ агарозном геле в $1 \times$ TВE-буфере, гели окрашивали бромистым этидием и фотографировали в ультрафиолетовом свете.

\section{Результаты и обсуждение}

Большинство озимых и яровых образцов амфиплоидов, полученных из разных генбанков, характеризовались разным уровнем устойчивости к бурой ржавчине в полевых условиях Харьковской области (табл. 3, А, Б), за исключением образцов из коллекции Международного центра по улучшению кукурузы и пшеницы - СІММҮТ (Мексика) (см. табл. 3, В). Так, среди 67 изученных амфиплоидов 58 \% образцов имели высокий уровень устойчивости (баллы 9 и 8), 22 \% - умеренную устойчивость (баллы 7 и 6) и $18 \%$ - умеренную восприимчивость (балл 5) (см. табл. 3). Амфиплоиды из коллекции СІММYТ отличались разной степенью восприимчивости (баллы от 2 до 5), за исключением единственного образца 14009 (CROC_1/Ae. squarrosa (517), балл 8) (см. табл. 3, В).

В условиях Новосибирской области у изученной коллекции амфиплоидов тоже выявлена высокая частота (78\%) форм, устойчивых к бурой ржавчине (пораженность от 0 до 5 \%) (табл. 4). Только у трех образцов KU 221-23, KU 222, tetraCantach + Ae. squarrosa RL 5261 наблюдали высокую восприимчивость к болезни (65-100\%). Образцы, выделенные как устойчивые в условиях Новосибирска, также были резистентны в Харькове (например, ПАГ-5, ПАГ-13, ПАГ-32 и др.).

В лабораторных условиях в фазе проростков изучено 40 образцов амфиплоидов. Реакцию устойчивости к популяциям и тест-клонам P. triticina при инокуляции отрезков листьев и интактных растений показали два образца из Японии - KU 233 и KU 221-21 (табл. 5). Эти же образцы были резистентны в полевых условиях в Новосибирске. Амфидиплоид Жирова и T. kiharae (к-47897) проявили устойчивость к большинству популяций, за исключением омской. В полевых условиях T. kiharae (к-47897) характеризовался как иммунный, а амфидиплоид Жирова имел поражение до 5 \%. С использованием T. kiharae (к-47897) в ИЦиГ СО РАН со- 
Таблица 1. Характеристика по вирулентности инфекционного материала P. triticina

Table 1. The virulence characteristics of used infectious materials of $P$. triticina

\begin{tabular}{|c|c|c|c|c|c|c|c|c|c|}
\hline \multirow{3}{*}{$\begin{array}{l}\text { Линии сорта Thatcher, } \\
\text { изогенные по генам } L r \text {, } \\
\text { контролирующим } \\
\text { устойчивость к патогену }\end{array}$} & \multicolumn{9}{|c|}{ Тип реакции при инокуляции, баллы } \\
\hline & \multicolumn{6}{|c|}{ Популяции бурой ржавчины } & \multicolumn{3}{|c|}{ Тест-клоны } \\
\hline & $\begin{array}{l}\text { томская } \\
2010\end{array}$ & $\begin{array}{l}\text { омская } \\
2010\end{array}$ & $\begin{array}{l}\text { краснодар- } \\
\text { ская } 2010\end{array}$ & $\begin{array}{l}\text { ростовская } \\
2010\end{array}$ & $\begin{array}{l}\text { дагестан- } \\
\text { ская } 2010\end{array}$ & $\begin{array}{l}\text { дагестан- } \\
\text { ская } 2014\end{array}$ & kLr9 & kLr19 & kLr26 \\
\hline TCLr1 & 3 & 3 & 3 & 3 & 0 & 3 & 3 & 3 & 3 \\
\hline TcLr2a & 3 & 3 & $0-2$ & 0 & 0 & 0 & 3 & 3 & 3 \\
\hline TcLr2b & 3 & 3 & 3 & 3 & 3 & 0 & 3 & 3 & 3 \\
\hline TcLr2c & 3 & 3 & 3 & 3 & 3 & 3 & 3 & 3 & 3 \\
\hline TCLr9 & 0 & 0 & 0 & 0 & 0 & 0 & 3 & 0 & 0 \\
\hline TcLr15 & 3 & 3 & 0 & 0 & 0 & 0 & 3 & 3 & 3 \\
\hline TcLr19 & 0 & 0 & 0 & 0 & 0 & 0 & 0 & 3 & 0 \\
\hline TcLr20 & 3 & 3 & 3 & 3 & 3 & 3 & 3 & 3 & 3 \\
\hline TcLr23 & 3 & $1-2$ & 3 & 3 & 3 & $x$ & 2 & 2 & 2 \\
\hline TcLr24 & $0-1$ & $0-1$ & 0 & 0 & 0 & 0 & 0 & 0 & 0 \\
\hline TcLr26 & 0 & 3 & 3 & 0 & 3 & 3 & 0 & 0 & 3 \\
\hline TcLr44 & $x$ & 3 & $x$ & 3 & 3 & 3 & 2 & 2 & 3 \\
\hline Lr50 (KS96WGRC36) & 0 & 3 & 0 & 0 & 0 & $2-3$ & 0 & 0 & 0 \\
\hline
\end{tabular}

Примечание. Тс - сорт яровой мягкой пшеницы Thatcher.

Таблица 2. Последовательности праймеров, используемых для идентификации генов $\operatorname{lr}$ у амфиплоидов

Table 2. Sequences of primers used for identification of the $L r$ genes in amphidiploids

\begin{tabular}{|c|c|c|c|}
\hline Ген & Праймеры & Последовательность & Лит. источник \\
\hline \multirow[t]{2}{*}{ Lr1 } & WR003 F & GGGACAGAGACCTTGGTGGA & Qiu et al., 2007 \\
\hline & WR003 R & GACGATGATGATTTGCTGCTGG & \\
\hline \multirow[t]{2}{*}{ Lr9 } & SCS5F & TGCGCCCTTCAAAGGAAG & Gupta et al., 2005 \\
\hline & SCS5R & TGCGCCCTTCTGAACTGTAT & \\
\hline \multirow[t]{2}{*}{ Lr10 } & Fi.2245 & GTGTAATGCATGCAGGTTCC & Chelkowski et al., 2003 \\
\hline & Lr10-6/r2 & AGGTGTGAGTGAGTTATGTT & \\
\hline \multirow[t]{4}{*}{ Lr19 } & SCS265F & GGCGGATAAGCAGAGCAGAG & Gupta et al., 2006 \\
\hline & SCS265R & GGCGGATAAGTGGGTTATGG & \\
\hline & $\mathrm{GbF}$ & СAT CCT TGG GGA CCT C & Prins et al., 2001 \\
\hline & GbR & CCA GCT CGC ATA CAT CCA & \\
\hline \multirow[t]{2}{*}{ Lr2O } & STS638-L & ACAGCGATGAAGCAATGAAA & Neu et al., 2002 \\
\hline & STS638-R & GTCCAGTTGGTTGATGGAAT & \\
\hline \multirow[t]{2}{*}{ Lr24 } & Sr24\#12F & CACCCGTGACATGCTCGTA & Mago et al., 2005 \\
\hline & Sr24\#12L & AACAGGAAATGAGCAACGATGT & \\
\hline \multirow[t]{2}{*}{$L r 28$} & SCS421-L & ACA AGG TAA GTC TCC AAC CA & Cherukuri et al., 2005 \\
\hline & SCS421-R & AGT CGA CCG AGA TTTT TAA CC & \\
\hline \multirow[t]{2}{*}{ Lr34 } & csLV34F csLV34R & GTTGGTTAAGACTGGTGATGG & Lagudah et al., 2006 \\
\hline & & TGCTTGCTATTGCTGAATAGT & \\
\hline \multirow[t]{2}{*}{ Lr35 } & Sr39\#22rF & AGAGAAGATAAGCAGTAAACATG & Mago et al., 2009 \\
\hline & Sr39\#22rR & TGCTGTCATGAGAGGAACTCTG & \\
\hline \multirow[t]{2}{*}{ Lr37 } & Ventriup & AGGGGCTACTGACCAAGGCT & Helguera et al., 2003 \\
\hline & LN2 & TGCAGCTACAGCAGTATGTACACAAAA & \\
\hline \multirow[t]{2}{*}{$\operatorname{Lr} 39(=\operatorname{Lr} 41)$} & GDM35-L & ССTGCTCTGCCCTAGATACG & http://maswheat.ucdavis.edu/protocols/Lr39/ \\
\hline & GDM35-R & ATGTGAATGTGATGCATGCA & index.htm \\
\hline \multirow[t]{2}{*}{$1 B L \cdot 1 R S / 1 A L \cdot 1 R S$} & SCM9F & TGACAACCC CCTTTCCCTCGT & Weng et al., 2007 \\
\hline & SCM9R & TCATCGACGCTAAGGAGGACCC & \\
\hline \multirow[t]{2}{*}{ Lr47 } & PS10R & GCT GAT GAC CCT GAC CGG T & Helguera et al., 2000 \\
\hline & PS10L & TCT TCA TGC CCG GTC GGG T & \\
\hline
\end{tabular}


Таблица 3. Устойчивость амфиплоидов к бурой ржавчине в полевых условиях Харьковской области

Table 3. Resistance of amphidiploids to leaf rust in the Kharkov region field conditions

\begin{tabular}{|c|c|}
\hline Вид, образец, происхождение & $\begin{array}{l}\text { Устойчивость, } \\
\text { баллы }\end{array}$ \\
\hline \multicolumn{2}{|l|}{ А. Озимые } \\
\hline $\begin{array}{l}\text { Авролата (тетраАврора + Ae. umbellulata Zhuk.), PФ; T. aestivum L. } \times \text { Thinopyrum intermedium (Host) Barkworth \& } \\
\text { D.R. Dewey, Болгария; T. × boeoticourarticum Gandil., Армения }\end{array}$ & 9 \\
\hline T. × erebuni Gandil. (=syn. T. palmovae Ivanov), Армения & 8 \\
\hline UA 0500065 (Wheat × Thinopyrum ssp. (195/02)), Болгария & 7 \\
\hline АД 4 (T. dicoccoides (Koern. ex Aschers. et Graebn.) Schweinf. + Ae. biuncialis Vis.) & 6 \\
\hline
\end{tabular}

T. palmovae; Авротика (тетраАврора + Ae. mutica Boiss. (=syn. Amblyopyrum muticum (Boiss.) Eig), РФ;

Aegilotricum × cylindroaestivum Gandil., Армения; AD (T. boeoticum Boiss.+ Ae. uniaristata Vis.)

Б. Яровые

T. $\times$ tetramonocoсcum, Армения; T. $\times$ tetramonococcum (и-092820), ФРГ; T. $\times$ tetramonococcum, Беларусь;

T. $\times$ tetramonococcum, Армения; T. × sinskourarticum Gandil., Армения; T. kiharae Dorof. et Migush. (к-47897), Япония;

T. fungicidum Zhuk. (=syn. T. soveticum ssp. fungicidum (Zhuk.) N.P. Gontsch., РФ; АД (и-122190, T. dicoccum + Ae. speltoides), НИИГИС АН АзССР; АД 6 (T. turgidum L. + Ae. biuncialis), НИИГИС АН АзССР; АД 8 (Т. ispahanicum Heslot + Ae. triuncialis L.), НИИГИС АН АзССР; АД 9 (T. karamyschevii Nevski + Ae. triuncialis), НИИГИС АН АзССР; АД 12 (Т. turgidum + Ae. umbellulata), НИИГИС АН АзССР; АД 13 (Т. dicoccum + Ae. umbellulata), НИИГиС АН АзССР; КU 217 (к-45920, T. timopheevii + Ae. umbellulata), Япония; ПАГ-3 (и-088651, T. durum Desf. к-15312 + T. monococcum L. к-38555), РФ; ПАГ-5 (и-088650, Т. durum к-21966 + T. monococcum к-35915), РФ; ПАГ-13 (и-088657, Т. carthlicum Nevski к-32510 + T. monococcum к-35417), РФ; ПАГ-14 (и-088658, T. carthlicum к-32510 + T. monococcum к-35915), РФ; ПАГ-15 (и-088659, T. carthlicum к-1694 + T. monococcum к-39417), РФ; ПАГ-20 (T. timopheevii + T. monococcum), РФ; ПАГ-32 (T. dicoccum к-14055 + T. monococcum и-452639), РФ; ПЭАГ (Т. dicoccum и-244569 + Ae. squarrosa к-110), ДОС BИР, РФ

ПАГ-4 (T. durum к-16477 + T. monococcum к-18140), РФ; ПАГ-7* (и-088652, T. durum к-39781 + T. monococcum к-38555), РФ; ПАГ-8* (и-088653, Т. durum к-33067 + T. monococcum к-21308), РФ; ПАГ-9* (и-088654, T. durum к-35902 + T. monococcum к-21308), РФ; ПАГ-39 (T. dicoccum к-15007 + T. sinskajae A. Filat. et Kurk. к-48993), РФ; АД Жирова (T. militinae Zhuk. et Migusch. к-46007 + Ae. squarrosa), РФ; T. miguschovae Zhuk. (к-57361), РФ; T. timococcum Kost. (=syn. T. zhukovskyi Menabde et Erizjan, к-43805), ТСХА, РФ; ПАГ-1 (рыхлоколосая форма) (и-088646, T. durum к-8784 + T. monococcum к-20399), РФ; ПАГ-2 (рыхлоколосая форма) (и-088647, T. durum к-16501 + T. monococcum к-20399, РФ; T. × monococcourarticum Gandil., Армения; ×Haynatricum Zhuk. (к-38259, Haynaldia villosa (L.) Schur (=syn. Dasypyrum villosum (L.) Borbas) + T. dicoccum), PФ; T. flaksbergeri Navr. (k-55251), PФ

ПАГ-12* (T. carthlicum к-34582 + T. monococcum к-35914), РФ; ПАГ-31 (T. dicoccum и-329428, Польша + T. monococcum к-20636), РФ; AS 6 (и-497381), Франция; T. timonovum Heslot et Ferarry (к-43065), Франция; T. × sinskourarticum Gandil., Армения

$\times$ Tritordeum (Bg013258, T. durum + Hordeum chilense Roem. \& Schult.), Испания; ×Tritordeum (Bg013259, T. durum + H. chilense), Испания; $\times$ Tritordeum (Bg020173, T. durum + H. chilense), Испания; $\times$ Tritordeum (Bg020174, T. durum + H. chilense), Испания; $\times$ Tritordeum (Bg020176, T. durum + H. chilense), Испания; AS 7 (и-497382), Франция; KU 221-14 (к-45923, T. durum KU 134 + Ae. squarrosa KU 2076), Япония; ПАГ-8* (и-088653), РФ

АД 8 (T. dicoccum + Ae. triuncialis), Азербайджан; АД 7 (T. ispahanicum + Ae. cylindrica Host), PФ; AD-100 (T. durum × Ae. longíssima Schweinf. \& Muschl.), РФ; АД-102 (Ae. ventricosa Tausch $\times$ T. dicoccum), РФ; КU 221-12 (К-45924, T. dicoccoides KU 109 + Ae. squarrosa KU 2074), Япония; ПАГ-1 («милитиноиды») (и-088646), РФ; ПАГ-7* (и-088652), РФ;

ПАГ-9* (и-088654), РФ

KU 221-4 (T. carthlicum KU 138 + Ae. squarrosa KU 20-2), Япония; АД (T. carthlicum + Ae. speltoides), НИИГиС АН АзССР 4

АД (T. dicoccum + Ae. biuncialis), НИИГИС АН АзССР

В. Амфиплоиды $(2 n=42)$ с геномом BBAADD из коллекции СIMMYT

14009 CROC_1/Ae. squarrosa (517)

13931 D67.2/P66.270//Ae. squarrosa (217); 13974 D67.2/P66.270//Ae. squarrosa (257)

13933 D67.2/P66.270//Ae. squarrosa (218); 13937 DVERD_2/Ae. squarrosa (221); 13954 DOY1/Ae. squarrosa (515);

14012 CETA/Ae. squarrosa (1027) CIGM93.406

5

13948 68.112/WARD//Ae. squarrosa (369); 13953 68.111/RGB-U//WARD/3/Ae. squarrosa; 13960 YAR/Ae. squarrosa (783);

13992 YAV_2/TEZ//Ae. squarrosa (895); 14002 GREEN/Ae. squarrosa (458); 14010 CETA/Ae. squarrosa (1024);

14011 DVERD_2/Ae. squarrosa (1027)

13975 LCK59.61/Ae. squarrosa (313); 13976 LCK59.61/Ae. squarrosa (324); 13993 ARLIN/Ae. squarrosa (283); 13999 68.111/RGB-U//WARD/3/Ae. squarrosa; CIGM92.1721; 14003 CETA/Ae. squarrosa (174)

* В разные годы у одного и того же образца была разная устойчивость. 
Таблица 4. Устойчивость амфиплоидов к бурой ржавчине на фитоучастке СибНИИРС

(Краснообск, Новосибирская область)

Table 4. Amphidiploids resistance to leaf rust in fungi test field of SibRIPPB (Krasnoobsk, Novosibirsk region)

Вид, образец, происхождение

Пораженность, \%

T. kiharae (K-47897)*; KU 233 (T. timopheevii + T. monococcum); KU 221-21 (T. carthlicum KU $138+$ Ae. squarrosa 0

KU 2084), Япония; ПАГ-5 (и-088650)*; ПАГ-8 (и-088653)*; ПАГ-11 (T. carthlicum к-13678 + T. monococcum

К-35915), РФ; ПАГ-20*; ПАГ-31*; ПАГ-32*; ПАГ-39*; ПЭАГ*; КU 229-2 (T. turgidum KU $147+$ T. monococcum KU 105),

Япония

KU 221-13 (T. dicoccum KU 124 + Ae. squarrosa KU 2074), Япония; tetraCantach + Ae. squarrosa RL 5588, Канада;

$0+$ некроз ПАГ-9 (и-088654)*; ПАГ-13 (и-088657)*

KU 218 (T. timopheevii + T. monococcum), Япония; ПАГ-12* $0-1$

АД Жирова*; Haynatricum (к-38259)* 5

KU 221-24 (T. dicoccum KU 147+ Ae. squarrosa KU 2075), Япония

40

KU 221-23 (T. orientale Perc. (=syn. T. turanicum Jakubz.) KU 137 + Ae. squarrosa KU 2074), Япония

65

KU 222 (T. dicoccum cv. Vernal + Ae. squarrosa); tetraCantach + Ae. squarrosa RL 5261, Канада;

сорт яровой мягкой пшеницы Скала (контроль)

* Происхождение см. в табл. 3, Б.

Таблица 5. Устойчивость амфиплоидов к бурой ржавчине в фазе проростков

Table 5. Resistance of amphidiploids to leaf rust in the seedling phase

\begin{tabular}{|c|c|c|c|c|c|c|c|c|c|c|}
\hline \multirow[t]{4}{*}{ Образец* } & \multicolumn{10}{|c|}{ Тип реакции, баллы } \\
\hline & \multicolumn{6}{|c|}{ Отрезки листьев } & \multicolumn{4}{|l|}{ Проростки } \\
\hline & \multicolumn{5}{|c|}{ Популяции P. triticina } & \multirow{2}{*}{$\begin{array}{l}\text { Тест- } \\
\text { клон } \\
\text { kLr9 }\end{array}$} & \multirow{2}{*}{$\begin{array}{l}\text { Дагестанская } \\
\text { популяция } 2014\end{array}$} & \multicolumn{3}{|c|}{ Тест-клоны } \\
\hline & $\begin{array}{l}\text { томская } \\
2010\end{array}$ & $\begin{array}{l}\text { омская } \\
2010\end{array}$ & $\begin{array}{l}\text { ростов- } \\
\text { ская } 2010\end{array}$ & $\begin{array}{l}\text { краснодар- } \\
\text { ская } 2010\end{array}$ & $\begin{array}{l}\text { дагестан- } \\
\text { ская } 2010\end{array}$ & & & kLr9 & kLr19 & kLr26 \\
\hline KU 233 & $0-2$ & $0-1$ & 0 & $0-1$ & 0 & 0 & 0 & 0 & 0 & 0 \\
\hline KU 221-21 & 0 & 0 & 0 & 0 & 0 & 0 & 0 & 0 & 0 & 0 \\
\hline АД Жирова & $1-2$ & 3 & $0-1$ & $1-2$ & 0 & 0 & $0-1$ & $-^{* *}$ & $-* *$ & $-^{* *}$ \\
\hline T. kiharae (к-47897) & 0 & 3 & $0-1$ & 0 & 0 & 0 & $2+$ & $-* *$ & $-^{* *}$ & $-* *$ \\
\hline ПАГ-32 & $x$ & $x$ & $0-1$ & $x$ & 0 & 3 & $x$ & $--^{* *}$ & $-* *$ & $-* *$ \\
\hline KU 229-2 & $x$ & 0 & $x$ & $x$ & $x$ & 0 & $x$ & $--^{* *}$ & $-* *$ & $-* *$ \\
\hline ПЭАГ & 0 & 3 & $0 ; 3^{* * *}$ & $0 ; 3^{* * *}$ & $0 ; 3^{* * *}$ & 3 & 0 & 0 & 0 & 0 \\
\hline ПАГ-20 & 3 & 3 & 3 & 3 & $0-1$ & 0 & 3 & $0 ; 1$ & 0 & 0 \\
\hline ПАГ-5 & 3 & 3 & 3 & 3 & 3 & 3 & 3 & 0 & 0 & 3 \\
\hline KU 218 & $x$ & $x$ & $1-2$ & $x$ & $x$ & 3 & 3 & 0 & 0 & 0 \\
\hline AD-103 & 3 & 3 & 3 & 3 & 3 & 0 & 3 & $2^{+}$ & $0-1$ & 2 \\
\hline KU 217 & 3 & 3 & $1-2$ & 3 & 3 & 0 & 3 & 0 & $0-1$ & 0 \\
\hline Tritordeum Bg020173 & 3 & 3 & 3 & 3 & 3 & 2 & 3 & $1-2$ & 0 & $x$ \\
\hline $\begin{array}{l}\text { Agilotriticum } \\
\text { cylindroaestivum }^{* * * *}\end{array}$ & 3 & 3 & 3 & 3 & 3 & 3 & 3 & 3 & 3 & 3 \\
\hline \multicolumn{11}{|c|}{$\begin{array}{l}\text { Примечание. Цветом выделены самые устойчивые образцы. } \\
\text { * Происхождение для данных и восприимчивых образцов (последняя строка), приведенных в последнем примечании, см. в табл. 3, В и } \\
\text { табл. 4; }\end{array}$} \\
\hline \multicolumn{11}{|c|}{$\begin{array}{l}\text { **** восприимчивость ко всем популяциям и клону выявлена также у T. flaksbergerii (К-55251), ПАГ-8, ПАГ-9, ПАГ-11, ПАГ-12, ПАГ-13, ПАГ-31, } \\
\text { ПАГ-39, KU 221-1b (T. dicoccoides + Ae. squarrosa), KU 221-12 (T. dicoccoides + Ae. squarrosa), KU 221-13, KU 221-23, KU 221-25 (T. durum + Ae. squar- } \\
\text { rosa), KU 222, tetraCantach + Ae. squarrosa RL 5261, tetraCantach + Ae. squarrosa RL 5571, tetraCantach + Ae. squarrosa RL 5588, AD-100, AD-101 } \\
\text { (T. turgidum (TTR 19) + Ae. squarrosa (TQ27)), AD-102, Agroticum 3Ag14/*'*ondor, KU 231-2 (T. araraticum Jakubz. + Ae. squarrosa), Haynatricum } \\
\text { (к-38259), KU 221-24. }\end{array}$} \\
\hline
\end{tabular}



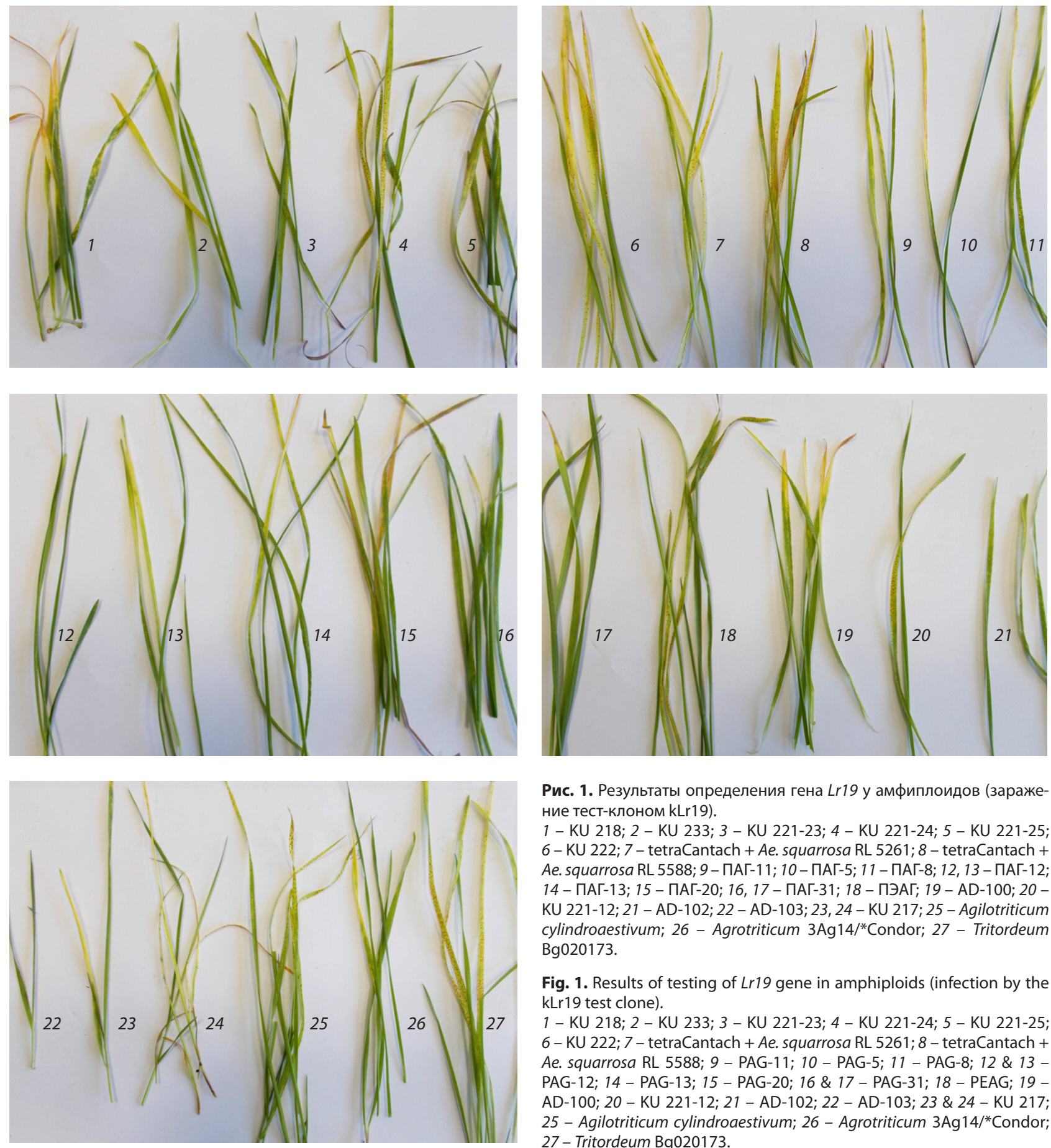

Рис. 1. Результаты определения гена Lr19 у амфиплоидов (заражение тест-клоном kLr19).

1 - KU 218; 2 - KU 233; 3 - KU 221-23; 4 - KU 221-24; 5 - KU 221-25; 6 - KU 222; 7 - tetraCantach + Ae. squarrosa RL 5261; 8 - tetraCantach +

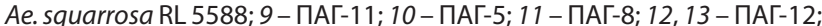
14 - ПАГ-13; 15 - ПАГ-20; 16, 17 - ПАГ-31; 18 - ПЭАГ; 19 - АD-100; 20 KU 221-12; 21 - AD-102; 22 - AD-103; 23, 24 - KU 217; 25 - Agilotriticum cylindroaestivum; 26 - Agrotriticum $3 \mathrm{Ag} 14 /{ }^{*}$ Condor; 27 - Tritordeum Bg020173.

Fig. 1. Results of testing of $L r 19$ gene in amphiploids (infection by the kLr19 test clone).

1 - KU 218; 2 - KU 233; 3 - KU 221-23; 4 - KU 221-24; 5 - KU 221-25; 6 - KU 222; 7 - tetraCantach + Ae. squarrosa RL 5261; 8 - tetraCantach + Ae. squarrosa RL 5588; 9 - PAG-11; 10 - PAG-5; 11 - PAG-8; 12 \& 13 PAG-12; 14 - PAG-13; 15 - PAG-20; 16 \& 17 - PAG-31; 18 - PEAG; 19 AD-100; 20 - KU 221-12; 21 - AD-102; 22 - AD-103; 23 \& 24 - KU 217; 25 - Agilotriticum cylindroaestivum; 26 - Agrotriticum 3Ag14/*Condor; 27 - Tritordeum Bg020173.

вместно с Омским аграрным центром получен сорт яровой мягкой пшеницы Памяти Майстренко (Лайкова и др., 2013), который в условиях Западно-Сибирского региона характеризуется устойчивостью к бурой ржавчине. Ранее амфиплоид к-47897 был описан как новый вид пшеницы T. kiharae В.Ф. Дорофеевым и Э.Ф. Мигушовой (Чикида, 2020).

При инокуляции интактных проростков амфиплоидов ПАГ-32 и KU 229-2 дагестанской популяцией P. triticina выявлена умеренная восприимчивость (балл X). Тип реакции на отрезках варьировал в зависимости от используемой популяции. В полевых условиях образцы ПАГ-32 и КU 229-2 высокоустойчивы к бурой ржавчине.

У амфиплоидов ПАГ-20, KU 218, AD-103, KU 217, Tritordeum Bg020173 наблюдали варьирование типа реакции от устойчивого до восприимчивого в зависимости от используемой популяции патогенов. В фазе взрослых растений высоким уровнем устойчивости (симптомы поражения отсутствовали) характеризовались амфиплоиды ПАГ-20 и KU 218, у амфиплоида KU 221-24 поражение достигало $40 \%$.

Все другие изученные амфиплоиды (57 \%) были универсально восприимчивыми при инокуляции отрезков листьев и интактных растений. У амфиплоида ПЭАГ (T. dicoccum $\times$ Ae. squarrosa) наблюдалась неоднородность внутри образца по устойчивости к бурой ржавчине. 


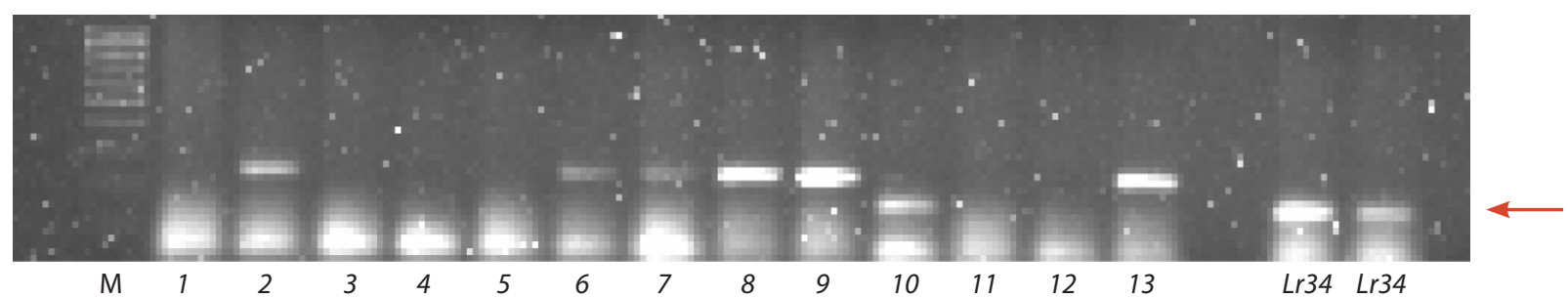

Рис. 2. Электрофореграмма продуктов ПЦР амплификации гена Lr34.

M - маркер молекулярной массы. 1 - ПАГ-32; 2 - ПЭАГ; 3 - AD-100; 4 - KU 221-12; 5 - AD-102; 6 - AD-103; 7, 8 - KU 217; 9 - Agilotriticum cylindroaestivum; 10 - Agrotriticum 3Ag14/*Condor; 11 - Tritordeum Bg020173; 12 - AD-7; 13 - T. уunnanense (KU 509); Lr34 - изогенная линия Thatcher с геном Lr34. Стрелкой указан диагностический продукт размером 150 п. н.

Fig. 2. Electrophoregram of $P C R$ amplification products of the $L r 34$ gene.

M - marker of molecular weight. 1 - PAG-32; 2 - PEAG; 3 - AD-100; 4 - KU 221-12; 5 - AD-102; 6 - AD-103; 7 \& 8 - KU 217; 9 - Agilotriticum cylindroaestivum; 10 - Agrotriticum 3Ag14/*Condor; 11 - Tritordeum Bg020173; 12 - AD-7; 13 - T. yunnanense (KU 509); Lr34 - the Lr34 gene nearisogenic $\mathrm{cv}$. Thatcher line. The arrow indicates a diagnostic product with a size of $150 \mathrm{bp}$.
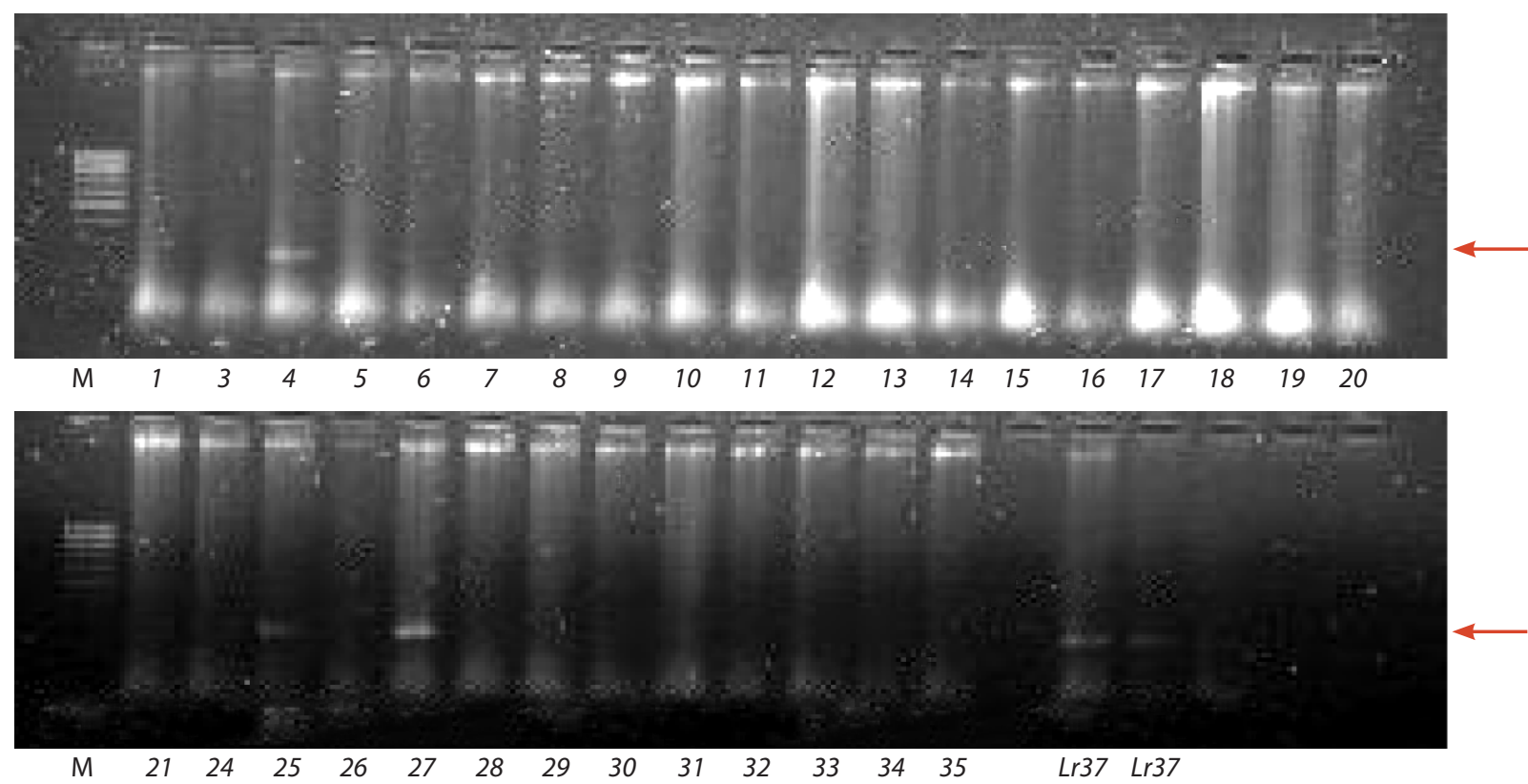

Рис. 3. Электрофореграмма продуктов ПЦР амплификации гена Lr37.

М - маркер молекулярной массы. 1 - KU 218; 3 - T. kiharae (к-47897); 4 - KU 233; 5 - KU 221-23; 6 - KU 221-24; 7 - KU 221-25; 8 - KU 222; 9 - tetraCantach + Ae. squarrosa RL 5261; 10 - tetraCantach + Ae. squarrosa RL 5588; 11 - ПАГ-11; 12 - ПАГ-5; 13 - ПАГ-8; 14 - ПАГ-9; 15, 16 - ПАГ-12; 17- ПАГ13; 18 - ПАГ-20; 19, 20 - ПАГ-31; 21 - ПАГ-32; 24 - ПЭАГ; 25 - AD-100; 26 - KU 221-12; 27 - AD-102; 28 - AD-103; 29,30 - KU 217; 31 - Agilotriticum cylindroaestivum; 32 - Agrotriticum 3Ag14/*Condor; 33 - Tritordeum Bg020173; 34 - AD-7; 35 - KU 509; Lr37 - изогенная линия Thatcher с геном Lr37. Стрелкой указан диагностический продукт размером 259 п.н.

Fig. 3. The electrophoretogram of PCR amplification products of the $L r 37$ gene.

$\mathrm{M}$ - Marker of molecular weight. 1 - KU 218; 3 - T. kiharae (k-47897); 4 - KU 233; 5 - KU 221-23; 6 - KU 221-24; 7 - KU 221-25; 8 - KU 222; 9 - tetraCantach + Ae. squarrosa RL 5261; 10 - tetraCantach + Ae. squarrosa RL 5588; 11 - PAG-11; 12 - PAG-5; 13 - PAG-8; 14 - PAG-9; 15 \& 16 - PAG-12; 17 - PAG-13; 18 - PAG-20; 19 \& 20 - PAG-31; 21 - PAG-32; 24 - PEAG; 25 - AD-100; 26 - KU 221-12; 27 - AD-102; 28 - AD-103; 29 \& 30 - KU 217; 31 Agilotriticum cylindroaestivum; 32 - Agrotriticum 3AG14/*Condor; 33 - Tritordeum BG020173; 34 - AD-7; 35 - KU 509; Lr37 - Thatcher near-isogenic line with the $L r 37$ gene. The arrow indicates a diagnostic product with a size of $259 \mathrm{bp}$.

Более высокий уровень устойчивости в полевых условиях в фазе взрослых растений у большинства изученных амфиплоидов указывает на возрастной тип их устойчивости к бурой ржавчине (adult plant resistance). Для большинства амфиплоидов была отмечена корреляция результатов оценки устойчивости при инокуляции отрезков листьев и интактных растений. Реакция интактных проростков амфиплоидов на заражение тест-клоном kLr19 к гену Lr19 приведена на рис. 1.
С помощью ПЦР амплификации для 35 образцов амфиплоидов провели идентификацию высоко- и частично эффективных ювенильных генов устойчивости к бурой ржавчине $L r 9, L r 19, L r 24, L r 28, L r 39$ (=Lr41), Lr47, а также потерявших эффективность (малоэффективных) генов, имеющих широкое распространение в российских коммерческих сортах мягкой пшеницы, - Lr1, Lr10, Lr20, Lr26; и генов возрастной устойчивости Lr34, Lr35 и Lr37. В результате проведенного анализа у изученных амфиплоидов не обнаружено высоко- 

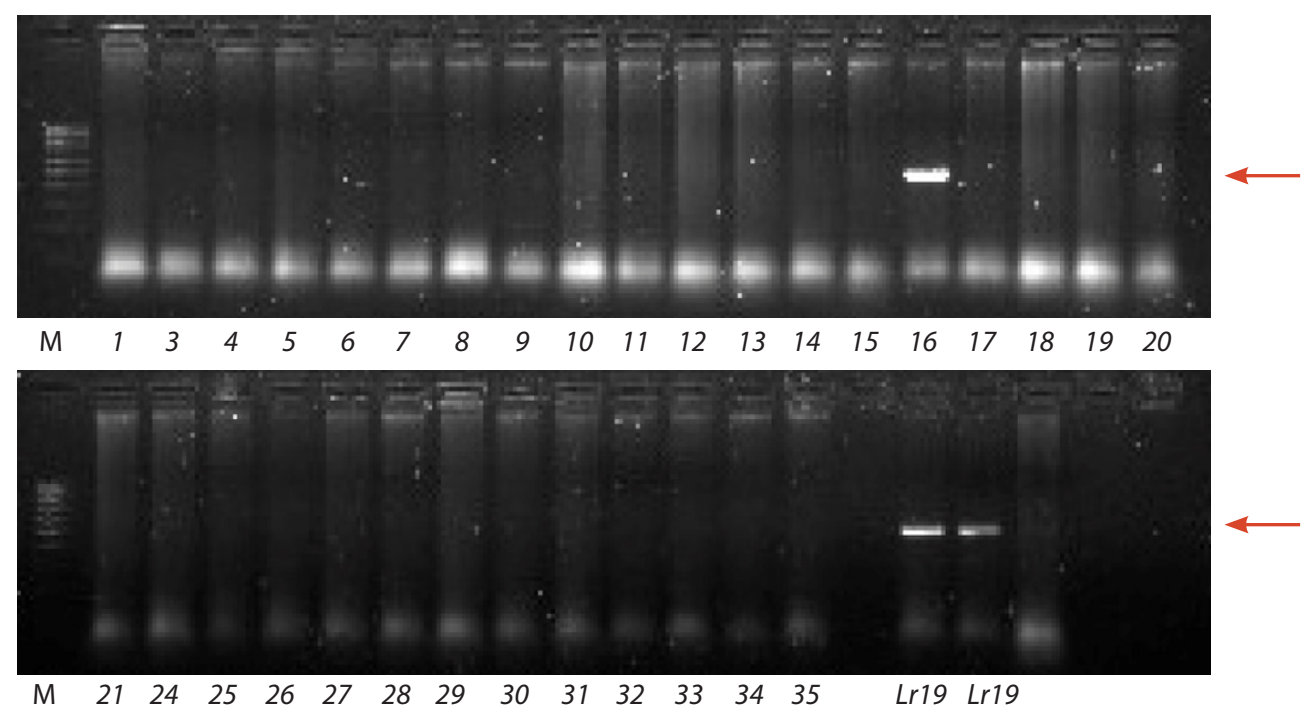

Рис. 4. Электрофореграмма продуктов ПЦР амплификации гена Lr19.

Список образцов см. в подписи к рис. 3. Стрелками указан диагностический продукт размером 512 п. н.

Fig. 4. Electrophoregram of PCR amplification products of the Lr19 gene.

A list of accessions see in Fig. 3.The arrows indicate a diagnostic product with a size of $512 \mathrm{bp}$.
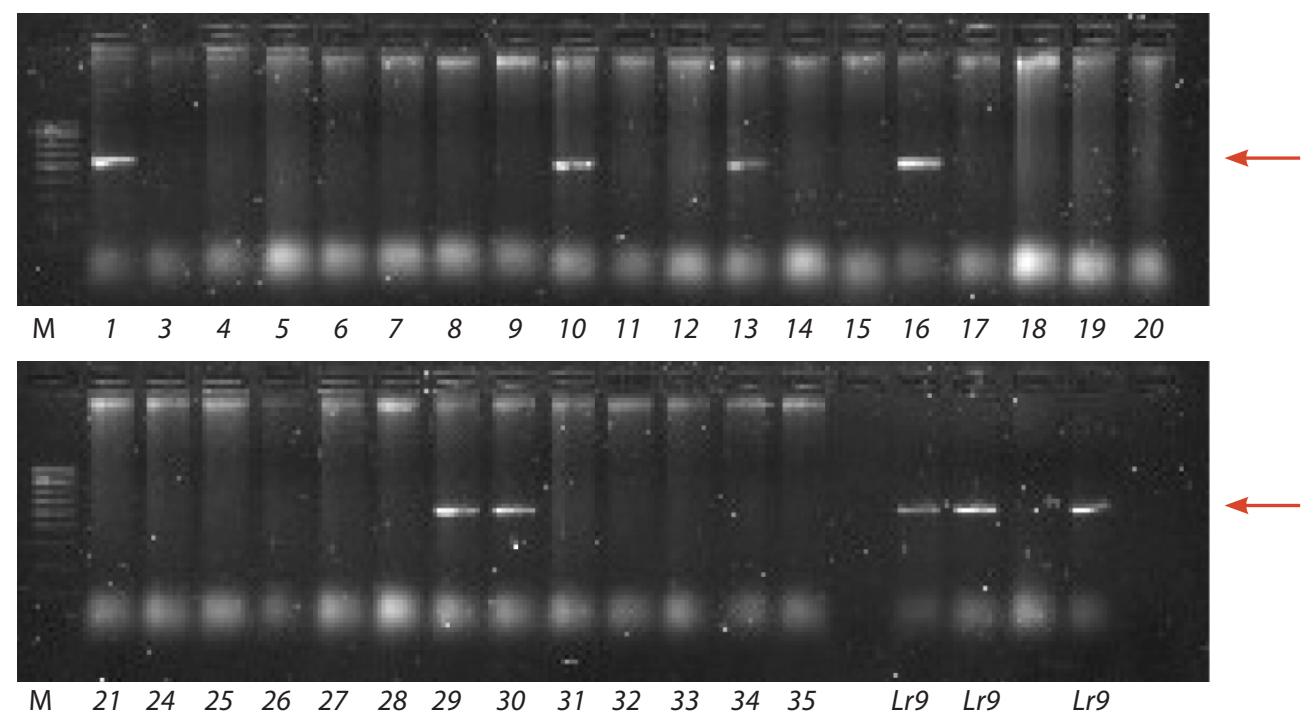

Рис. 5. Электрофореграмма продуктов ПЦР амплификации гена Lr9.

Список образцов см. в подписи к рис. 3. Стрелками указан диагностический продукт размером 550 п. н.

Fig. 5. Electrophoregram of PCR amplification products of the $\operatorname{Lr} 9$ gene.

A list of accessions see in Fig. 3.The arrows indicate a diagnostic product with a size of $550 \mathrm{bp}$.

эффективных генов устойчивости Lr24 (интрогрессирован в сорта мягкой пшеницы из Agropyron elongatum (Host) Nevski (= syn. Thinopyrum ponticum (Podp.) Z.-W. Liu \& R.C. Wang), Lr41 (интрогрессирован из Ae. tauschii), Lr47 (интрогрессирован из Ae. speltoides) и малоэффективных генов Lr20 и Lr26 (интрогрессирован из ржи Secale cereale L.).

Малоэффективный ген $L r 1$ выявлен у четырех восприимчивых в фазе проростков амфиплоидов KU 222, tetraCantach + Ae. squarrosa RL 5261, tetraCantach + Ae. squarrosa RL 5588, Agilotriticum cylindroaestivum, а ген Lr10 - y tetraCantach + Ae. squarrosa RL 5588.
Транслокация 1AL/1RS (от Secale cereale) определена у амфиплоида Agroticum 3Ag14/*Condor. Наряду с этой транслокацией у него обнаружен ген возрастной устойчивости Lr34 (рис. 2). Ген Lr37 (от Ae. ventricosa), также детерминирующий устойчивость в фазе взрослых растений, выявлен у высокоустойчивого в фазе проростков KU 233 и восприимчивых AD-100 и AD-102 (рис. 3).

Праймер SCS265 гена Lr19 (интрогрессирован в пшеницу из Ag. elongatum) амплифицировался у восприимчивого в фазе проростков образца ПАГ-12 (рис. 4). Таким образом, выявлено несоответствие результатов молеку- 
лярного и фитопатологического скринингов. Аналогичная неоднозначность была получена с праймером для гена Lr9 (от Ae. umbellulata) у образцов tetraCantach + Ae. squarrosa RL 5588, ПАГ-8, ПАГ-12, KU 218 и KU 217, несмотря на то, что у амфиплоида KU 217 в родословной есть Ae. umbellulata (рис. 5). Кроме гена Lr9, у KU 217 выявлен ген Lr28. Ранее нами была показана недостаточная специфичность маркера гена Lr28. Этот маркер также амплифицируется у образцов с генетическим материалом T. timopheevii (Гультяева и др., 2014). Вероятно, это и наблюдалось в данном случае, поскольку в родословной амфиплоида KU 217 присутствует вид T. timopheevii.

Большинство изученных в нашей работе амфиплоидов были созданы с использованием видов рода Aegilops L. и диких и выведенных из возделывания видов пшениц, поскольку a priori долгое время считалось, что они несут в том числе и гены устойчивости. Они создавались с различными сочетаниями геномов с целью как изучения их взаимодействия, так и использования в качестве видов-мостов для переноса генов, контролирующих интересующие исследователей и селекционеров хозяйственно важные признаки, в возделываемые виды пшениц (Valkoun et al., 1986). Как уже отмечено ранее, для создания устойчивых к болезням амфиплоидов необходимо брать в качестве исходных форм абсолютно устойчивые к болезням оба родительских компонента либо абсолютно устойчивый первый и относительно устойчивый второй (Таврин, 1989), т. е. необходимо добиваться устойчивости у амфиплоида за счет объединения в одном геноме нескольких генов, ее контролирующих. В случае же одного неустойчивого родительского компонента скрещивания снижается эффективность их длительного использования в качестве исходного материала для селекции. Все амфиплоиды tetraCantach + Ae. squarrosa потеряли устойчивость, хотя их отцовские компоненты ранее (в 1970-1980-е годы) были устойчивыми, так как Ae. squarrosa перед порядковым номером имеют символы RL (от англ. resistance line).

Кроме того, в настоящее время не существует стройных концепций, объясняющих феномен интрогрессии генов из других видов. Одной из основных проблем, возникающих после получения таких отдаленных гибридов, становятся вопросы собственно интрогрессии признаков. Для этого необходимо ответить на вопрос об одинаковом фенотипическом проявлении гомологических мутаций у разных видов, их генетическом контроле и экспрессии генов в разных генофонах. Известно, что добавление генома D к тетраплоидному компоненту может снижать устойчивость гексаплоидного амфиплоида (Пухальский, 2005).

Считается, что одна из возможных неудач при проведении интрогрессивной гибридизации состоит в том, что не всегда происходит успешная рекомбинация генетического материала. Однако это может быть также следствием отсутствия экспрессии генов в новом генофоне, что в конечном итоге будет проявляться как отсутствие признака. Поэтому для решения поставленной проблемы необходимы дальнейшие исследования экспрессии генов как вида-донора, так и вида-реципиента на различном уровне плоидности, что может быть достигнуто при использовании модели «гомологичные признаки (гены)». Комплексные исследования такого плана нигде в мире практически не ведутся. Известны только единичные работы. Механизмы устойчивости могут быть основаны и на изменении микроморфологических и химических показателей тканей листа и стебля, в частности на степени лигнификации и содержании кремниевых соединений в их тканях (Коновалов и др., 2017; Карпова и др., 2019).

\section{Заключение}

В заключение заметим, что выборка случайно взятых 108 амфиплоидов по большому счету оказалась не репрезентативной по эффективным генам устойчивости к бурой (листовой) ржавчине. В то же время не все образцы, созданные в ВИР Э.В. Тавриным в 1960-е годы, к настоящему времени полностью потеряли устойчивость. Отметим, что не следует скрещивать всё со всем для получения амфиплоидов (см. табл. 3, В). Вероятно, при массовом создании амфиплоидов необходимо провести предварительную оценку родительских компонентов по интересующему исследователей признаку. Наличие информации о родословных потенциальных родительских форм (Мартынов и др., 2015) не всегда позволяет сделать прогноз устойчивости потомков от скрещивания мягкой пшеницы как с эгилопсами, так и с выведенными из возделывания видами пшениц.

\section{Список литературы / References}

Афанасенко О.С., Мироненко Н.В., Анисимова А.В., Баранова О.А. Зубкович А.А., Марчук О.В., Муругова Г.А. Изменение видового состава возбудителей листовых болезней ячменя в России и Беларуси. Дьяков Ю.Т., Сергеев Ю.В. (Ред.). Современная микология в России. Т. 5: Материалы III Междунар. микол. форума. Москва, 14-15 апр. 2015 г. М.: Нац. акад. микологии, 2015; 5-7. DOI 10.14427/cmr.2015.v.10.

[Afanasenko O.S., Mironenko N.V., Anisimova A.V., Baranova O.A., Sobkovich A.A., Marchuk O.V., Murugova G.A. Changes in the species composition of pathogens of leaf diseases of barley in Russia and Belarus. In: Dyakov Yu.T., Sergeev Y.V. (Eds.). Modern Mycology in Russia. Vol. 5: Proc. of the 3rd Int. mycological forum. Moscow, 14-15 April 2015. Moscow: National Academy of Mycology, 2015; 5-7. DOI 10.14427/cmr.2015.v.10. (in Russian)]

Гончаров Н.П. Сравнительная генетика пшениц и их сородичей. Новосибирск: Академическое изд-во «Гео», 2012.

[Goncharov N.P. Comparative Genetics of Wheats and their Related Species. Novosibirsk: Acad. Publ. House "Geo", 2012. (in Russian)]

Гультяева Е.И., Орина А.С., Ганнибал Ф.Б., Митрофанова О.П., Одинцова И.Г., Лайкова Л.И. Эффективность молекулярных маркеров для выявления генов Lr28, Lr35 и Lr47 у мягкой пшеницы. Генетика. 2014;50(2):147-147. DOI 10.7868/S0016675814020064.

[Gultyaeva E.I., Orina A.S., Gannibal P.B., Mitrofanova O.P., Odintsova I.G., Laikova L.I. The effectiveness of molecular markers for the identification of $L r 28, L r 35$, and $L r 47$ genes in common wheat. Russ. J. Genet. 2014;50(2):131-139. DOI 10.1134/S1022795414020069.]

Давоян Р.О., Бебякина И.В., Давоян О.Р., Зинченко А.Н., Давоян Э.Р., Кравченко А.М., Зубанова Ю.С. Синтетические формы как основа для сохранения и использования генофонда диких сородичей мягкой пшеницы. Вавиловский журнал генетики и селекции, 2014; 16(1):44-51.

[Davoyan R.O., Bebyakina I.V., Davoyan O.R., Zinchenko A.N., Davoyan E.R., Kravchenko A.M., Zubanova Yu.S. Use of synthetic forms in the preservation and exploitation of the gene pool of wild common wheat relatives. Vavilovskii Zhurnal Genetiki i Selektsii = Vavilov Journal of Genetics and Breeding. 2014;16(1):44-51. (in Russian)]

Дорохов Д.Б., Клоке Э. Быстрая и экономичная технология RAPD анализа растительных геномов. Генетика. 1997;33(4):443-450. [Dorokhov D.B., Kloke E. Rapid and economical technology of RAPD analysis of plant genomes. Russ. J. Genet. 1997;33(4):358-365.] 
Жиров Е.Г., Терновская Т.К. Передача пшенице Triticum aestivum L. хромосомы Aegilops sharonensis Eig, придающей ей устойчивость к мучнистой росе. Генетика. 1993;29(4):639-645.

[Zhirov E.G., Ternovskaya T.K. Transfer to the wheat Triticum aestivum L. of an Aegilops sharonensis Eig chromosome conferring resis tance to powdery mildew. Genetika (Moskva). 1993;29(4):639-645. (in Russian)]

Зарубайло Т.Я., Таврин Э.В. Новые аллогексаплоиды пшеницы, их плодовитость и устойчивость к болезням. Науч.-техн. бюл. ВНИИ растениеводства. 1972;24:30-34.

[Zarubaylo T.Ya., Tavrin E.V. New allohexaploids of wheat, their fertility and resistance to diseases. Naucno-techn. Byul. Research Institute of Plant Industry. 1972;24:30-34. (in Russian)]

Карпова Е.В., Шундрина И.К., Орлова Е.А., Коновалов А.А. Ароматические и минеральные вещества в тканях образцов яровой мягкой пшеницы Triticum aestivum L., различающихся по устойчиво сти к бурой ржавчине (возбудитель Puccinia triticina Erikss.). Химия растит. сырья. 2019;4:87-95. DOI 10.14258/jcprm.2019045238. [Karpova Ye.V., Shundrina I.K., Orlova Ye.A., Konovalov A.A. Aromatic and mineral substances in the tissues of the samples of spring com mon wheat Triticum aestivum L., differing in resistance to brown rust (pathogen Puccinia triticina Erikss.). Khimiya Rastitel'nogo Syr'ya. 2019;4:87-95. DOI 10.14258/jcprm.2019045238 (in Russian)]

Коновалов А.А., Шундрина И.К., Карпова Е.В., Ельцов И.В., Орлова Е.А., Гончаров Н.П. Влияние лигнификации и минерализации тканей листа на устойчивость к бурой ржавчине растений мягкой пшеницы. Вавиловский журнал генетики и селекции. 2017; 21(6):686-693. DOI 10.18699/VJ17.286.

[Konovalov A.A., Shundrina I.K., Karpova E.V., Eltsov I.V., Orlova E.A., Goncharov N.P. Influence of a lignification and mineralization of leaf tissues on resistance to a brown rust in common wheat plants. Vavilovskii Zhurnal Genetiki i Selektsii = Vavilov Journal of Genetics and Breeding. 2017;21(6):686-693. DOI 10.18699/VJ17.286. (in Russian)]

Лайкова Л.И., Белан И.А., Бадаева Е.Д., Россеева Л.П., Шепелев С.С., Шумный В.К., Першина Л.А. Создание и изучение сорта яровой мягкой пшеницы «Памяти Майстренко» с интрогрессией генетического материала от синтетического гексаплоида Triticum timopheevii Zhuk. $\times$ Aegilops tauschii Coss. Генетика. 2013;49(1): 103-112.

[Laikova L.I., Belan I.A., Badaeva E.D., Rosseeva L.P., Shepelev S.S., Shumny V.K., Pershina L.A. Development and study of spring bread wheat variety Pamyati Maystrenko with introgression of genetic material from synthetic hexaploid Triticum timopheevii Zhuk. Aegilops tauschii Coss. Russ. J. Genet. 2013;49(1):89-97.]

Леонова И.Н., Родер М.С., Калинина Н.П., Будашкина Е.Б. Генетический анализ и локализация локусов, контролирующих устойчивость интрогрессивных линий Triticum aestivum $\times$ Triticum timopheevii к листовой ржавчине. Генетика. 2008;44:1652-1659.

[Leonova I.N., Röder M.S., Kalinina N.P., Budashkina E.B. Genetic analysis and localization of loci controlling leaf rust resistance of Triticum aestivum $\times$ Triticum timopheevii introgression lines. Russ. J. Genet 2008;44(12):1652-1659. DOI 10.1134/S1022795408120077.]

Мартынов С.П., Добротворская Т.В., Митрофанова О.П. Генеалогический анализ распространения генетического материала эгилопсов (Aegilops L.) в сортах мягкой пшеницы (Triticum aestivum L.) Генетика. 2015;51(9):1000-1008. DOI 10.7868/S0016675815090076. [Martynov S.P., Dobrotvorskaya T.V., Mitrofanova O.P. Genealogical analysis of the use of goat grass (Aegilops L.) genetic material in wheat (Triticum aestivum L.). Russ. J. Genet. 2015;51(9):855-862. DOI 10.1134/S1022795415090070.]

Методические указания по исследованию устойчивости к возбу дителям заболеваний, к вредителям исходного и селекционного материала при выращивании в полевых условиях (зерновые злаки). Л., 1962.

[Methodological guidelines for the study of resistance to pathogens, pests of the initial and breeding material under growing in the field condition (cereals). Leningrad, 1962. (in Russian)]

Михайлова Л.А., Гультяева Е.И., Мироненко Н.В. Методы исследований структуры популяции возбудителя бурой ржавчины пшени цы: Сб. методических рекомендаций по защите растений. СПб. ВИЗР, 1998; 105-126.
[Mikhailova L.A., Gultyaeva E.I., Mironenko N.V. Methods for studying the structure of populations of the leaf rust causative agent. St. Petersburg: VIZR, 1998;105-126. (in Russian)]

Плотникова Л.Я., Мешкова Л.В., Гультяева Е.И., Митрофанова О.П., Лапочкина И.Ф. Тенденция преодоления устойчивости к бурой ржавчине интрогрессивных линий мягкой пшеницы с генетическим материалом Aegilops speltoides Tausch. Вавиловский журнал генетики и селекции. 2018;22(5):560-567. DOI 10.18699/VJ18.395. [Plotnikova L.Ya., Meshkova L.V., Gultyaeva E.I., Mitrofanova O.P., Lapochkina I.F. A tendency towards leaf rust resistance decrease in common wheat introgression lines with genetic material from Aegilops speltoides Tausch. Vavilovskii Zhurnal Genetiki i Selektsii = Vavilov Journal of Genetics and Breeding. 2018;22(5):560-567. DOI 10.18699/ VJ18.395. (in Russian)]

Потоцкая И.В., Шаманин В.П., Пожерукова В.Е., Гультяева Е.И., Моргунов А.И. Исходный материал с геномом Ae. tauschii для селекции на расонеспецифическую устойчивость к бурой и стеблевой ржавчине. Вестн. НГАУ. 2018;48(3):62-69. DOI 10.31677/2072-67242018-48-3-62-69.

[Pototskaia I.V., Shamanin V.P., Pozherukova V.E., Gultyaeva E.I., Morgunov A.I. Starting material with Ae. tauschii genome for selection to race non-specific resistance to brown rust and stem rust. Vestnik of Novosibirsk State Agrarian University. 2018;48(3):62-69. DOI 10.31677/2072-6724-2018-48-3-62-69. (in Russian)]

Пухальский В.А. Проблемы генетической теории селекции растений. Информ. вестн. ВОГИС. 2005;9(3):306-316.

[Puhalsky V.A. Problems of the genetic theory of plant breeding. Herald of Vavilov Society for Geneticists and Breeding Scientists. 2005; 9(3):306-316. (in Russian)]

Таврин Э.В. Аллополиплоидия и формообразование пшеницы. Труды по прикл. ботанике, генетике и селекции. 1989;128:45-52.

[Tavrin E.V. Allopolyploidy and morphogenesis in wheat. Trudy po Prikladnoy Botanike, Genetike i Selektsii = Proceedings on Applied Botany, Genetics, and Breeding. 1989;128:45-52. (in Russian)]

Чикида Н.Н. Вклад академика Владимира Филимоновича Дорофеева в развитие сельскохозяйственной и биологической наук. Письма в Вавиловский журнал генетики и селекции. 2020;6(1): 18-36. DOI 10.18699/Letters2020-6-4.

[Chikida N.N. Contribution of academician Vladimir Filimonovich Dorofeev to the development of agricultural and biological sciences. Pisma v Vavilovskii Zhurnal Genetiki i Selektsii = Letters to Vavilov Journal of Genetics and Breeding. 2020;6(1):18-36. DOI 10.18699/ Letters2020-6-4. (in Russian)]

Brozynska M., Furtado A., Henry R.J. Genomics of crop wild relatives: expanding the gene pool for crop improvement. Plant Biotechnol. J. First publ. 2015. Publ. 2016;14:1070-1085. DOI 10.1111/pbi.12454.

Catalogue of Aegilops-Triticum germ-plasm preserved in Kyoto University. Kyoto: Plant Germ-Plasm Institute, 1997/1998;2: 309 p. (with Supplement 41 p.).

Chelkowski J., Golka L., Stepien L. Application of STS markers for leaf rust resistance genes in near-isogenic lines of spring wheat $c v$. Thatcher. J. Appl. Genet. 2003;44(3):323-338.

Cherukuri D.P., Gupta S.K., Charpe A., Koul S., Prabhu K.V., Singh R.B., Haq Q.M.R. Molecular mapping of Aegilops speltoides derived leaf rust resistance gene Lr28 in wheat. Euphytica. 2005;143:19-26. DOI 10.1007/s10681-005-1680-6.

Das M.K., Bai G.H., Mujeeb-Kazi A., Rajaram S. Genetic diversity among synthetic hexaploid wheat accessions (Triticum aestivum) with resistance to several fungal diseases. Genet. Resour. Crop Evol. 2016; 63(8):1285-1296. DOI 10.1007/s10722-015-0312-9.

Edwards K., Johnstone C., Thompson C. A simple and rapid method for the preparation of plant genomic DNA for PCR analysis. Nucleic Acids Res. 1991;19(6):1349.

Gadimaliyeva G., Aminov N., Jahangirov A., Hamidov H., Abugalieva A., Shamanin V., Morgounov A. Productivity and disease resistance of primary hexaploid synthetic wheat lines and their crosses with bread wheat. Cereal Res. Commun. 2018:46(2):355-364. DOI 10.1556/ 0806.46.2018.16.

Goncharov N.P., Bannikova S.V., Kawahara T. Wheat artificial amphiploids involving Triticum timopheevii genome: their studies, preservation and reproduction. Genet. Resour. Crop Evol. 2007;54(7):15071516. DOI 10.1007/s10722-006-9141-1. 
Gupta S.K., Charpe A., Koul S., Prabhu K.V., Haq Q.M. Development and validation of molecular markers linked to an Aegilops umbellulataderived leaf rust resistance gene, Lr9, for marker-assisted selec tion in bread wheat. Genome. 2005;48(5):823-830. DOI 10.1139/ G05-051.

Gupta S.K., Charpe A., Prabhu K.W., Haque O.M.R. Identification and validation of molecular markers linked to the leaf rust resistance gene Lr19 in wheat. Theor. Appl. Genet. 2006;113(6):1027-1036. DOI 10.1007/s00122-006-0362-7.

Helguera M., Khan I.A., Dubcovsky J. Development of PCR markers for wheat leaf rust resistance gene Lr47. Theor. Appl. Genet. 2000;100(7): 1137-1143. DOI 10.1007/s001220051397.

Helguera M., Khan I.A., Kolmer J., Lijavetzky D., Zhong-Qi L., Dubcovsky J. PCR assays for the Lr37-Yr17-Sr38 cluster of rust resistance genes and their use to develop isogenic hard red spring wheat lines. Crop Sci. 2003;43(5):1839-1847. DOI 10.2135/cropsci2003.1839.

Kishii M. An update of recent use of Aegilops species in wheat breeding Front. Plant Sci. 2019;10:585. DOI 10.3389/fpls.2019.00585.

Lagudah E.S., McFadden H., Singh R.P., Huerta-Espino J., Bariana H.S., Spielmeyer W. Molecular genetic characterization of the $L r 34 / Y r 18$ slow rusting resistance gene region in wheat. Theor. Appl. Genet 2006;114:21-30. DOI 10.1007/s00122-006-0406-z.

Leonova I.N., Budashkina E.B., Kalinina N.P., Röder M.S., Börner A., Salina E.A. Triticum aestivum-Triticum timopheevii introgression lines as a source of pathogen resistance genes. Czech J. Genet. Plant Breed. 2011;47(spec.iss.):S49-S55.

Li A., Liu D., Yang W., Kishii M., Mao L. Synthetic hexaploid wheat: yesterday, today, and tomorrow. Engineering. 2018;4(4):552-558. DOI 10.1016/j.eng.2018.07.001.

Longin C.F.H., Würschum T. Back to the future - tapping into ancient grains for food diversity. Trends Plant Sci. 2016;21(9):731-737. DOI 10.1016/j.tplants.2016.05.005.

Mago R., Bariana H.S., Dundas I.S., Spielmeyer W., Lawrence G.J., Pryor A.J., Ellis J.G. Development or PCR markers for the selection of wheat stem rust resistance genes Sr24 and Sr26 in diverse wheat germplasm. Theor. Appl. Genet. 2005;111:496-504. DOI 10.1007/ s00122-005-2039-z.

Mago R., Zhang P., Bariana H.S., Verlin D.C., Bansal U.K., Ellis J.G., Dundas I.S. Development of wheat lines carrying stem rust resistance gene Sr39 with reduced Aegilops speltoides chromatin and simple PCR markers for marker-assisted selection. Theor. Appl. Genet. 2009; 124:65-70. DOI 10.1007/s00122-009-1146-7.

Mains E.B., Jackson H.S. Physiologic specialization in the leaf rust of wheat Puccinia triticina Erikss. Phytopathology.1926;16(2):89-120.

Majeeb-Kazi A., Rosas V., Roldan S. Conservation of the genetic variation of Triticum tauschii (Coss.) Schmalh. (Aegilops squarrosa auct. non L.) in synthetic hexaploid wheats (T. turgidum L. s. lat. $\times T$. taus chii; $2 n=6 x=42, A A B B D D$ ) and its potential utilization for wheat improvement. Genet. Resour. Crop Evol. 1996;43:129-143. DOI 10.1007/ BF00126756.
Morgounov A., Abugalieva A., Akan K., Akın B., Baenziger S., Bhatta M., Dababat A.A., Demir L., Dutbayev Ye., El Bouhssini M., ErginbaşOrakci G., Kishii M., Keser M., Koç E., Kurespek A., Mujeeb-Kazi A., Yorgancılar A., Özdemir F., Özturk I., Payne T.S., Qadimaliyeva G., Shamanin V., Subasi K., Suleymanova G., Yakişir E., Zelenskiy Yu. Highyielding winter synthetic hexaploid wheats resistant to multiple diseases and pests. Plant Genet. Res. Publ. online 2017. Publ. 2018; 16(3):273-278. DOI 10.1017/S147926211700017X.

Neu C.H., Stein N., Keller B. Genetic mapping of the Lr20 Pm 1 resistance locus reveals suppressed recombination on chromosome arm 7AL in hexaploid wheat. Genome. 2002;45(4):737-744. DOI 10.1139/g02-040.

Nyine M., Adhikari E., Clinesmith M., Jordan K.W., Fritz A.K., Akhunov E. Genomic patterns of introgression in interspecific populations created by crossing wheat with its wild relative. G3: Genes, Genomes, Genetics. 2020. DOI 10.1534/g3.120.401479.

Peterson R.F., Campbell A.B., Hannah A.E. A diagrammatic scale for estimating rust intensity on leaves and stems of cereals. Can. J. Res. 1948; 26(5):496-500. doi 10.1139/cjr48c-033.

Plamenov D., Spetsov P. Synthetic hexaploid lines are valuable resources for biotic stress resistance in wheat improvement. J. Plant Pathol. 2011:93(2):251-262. DOI 10.2307/41998995.

Prins R., Groenewald J.Z., Marais G.F., Snape J.W., Koebner R.M.D. AFLP and STS tagging of $L r 19$, a gene conferring resistance to leaf rust in wheat. Theor. Appl. Genet. 2001;103(4):618-624. DOI 10.1007/ PL00002918.

Qiu J.W., Schürch A.C., Yahiaoui N., Dong L.L., Fan H.-J., Zhang Z.-J., Keller B., Ling H.-Q. Physical mapping and identification of a candidate for the leaf rust resistance gene $L r 1$ of wheat. Theor. Appl. Genet. 2007;115:159-168. DOI 10.1007/s00122-007-0551-z.

Salina E.A., Egorova E.M., Adonina I.G., Susolkina N.V., Leonova I.N. The transfers of resistance genes from Triticum timopheevii and Aegilops speltoides to bread wheat using marker-assisted selection. Proc. Plant Genomics Eur. Meeting, Istanbul, May 4-7, 2011;94.

Spetsov P., Savov M. A review on amphidiploids in the Triticeae, obtained in Bulgaria during 1950-1990. Wheat Information Service. 1992;75:1-6.

Stoyanov H.P. Analysis and assessment of amphidiploids of TriticumAegilops group as a source of genetic diversity. Bulg. J. Agric. Sci. 2014;20(Suppl.1):173-178.

Valkoun J., Kučerova D., Bartoš P. Transfer of leaf rust resistance from Triticum monococcum L. to hexaploid wheat. Z. Pflanzenzüchtung. 1986;96(3):271-278.

Weng Y., Azhaguvel P., Devkota R.N., Rudd J.C. PCR-based markers for detection of different sources of $1 \mathrm{AL} \cdot 1 \mathrm{RS}$ and $1 \mathrm{BL} \cdot 1 \mathrm{RS}$ wheat-rye translocations in wheat background. Plant Breeding. 2007;126(5): 482-486. DOI 10.1111/j.1439-0523.2007.01331.x.

Zaharieva M., Ayana N.G., Al Hakimi A., Misra S.C., Monneveux P. Cultivated emmer wheat (Triticum dicoccon Schrank), an old crop with promising future: a review. Genet. Resour. Crop Evol. 2010;57:937-962. DOI 10.1007/s10722-010-9572-6. 